\title{
Misoprostol Vs Mifepristone and Misoprostol in Second Trimester Termination of Pregnancy
}

\author{
Nagaria Tripti $\cdot$ Sirmor Namrata
}

Received: 8 September 2009/Accepted: 24 October 2011/Published online: 14 February 2012

(C) Federation of Obstetric \& Gynecological Societies of India 2012

\begin{abstract}
Objective The present study was conducted with the aim to assess and comparatively evaluate the safety and efficacy of misoprostol alone and mifepristone with misoprostol for second trimester termination of pregnancy.

Methods and Materials The study was conducted on 200 selected cases, divided in two groups of 100 cases each. In the study group mifepristone was given $200 \mathrm{mg} 12 \mathrm{~h}$ before intravaginal insertion of $600 \mu \mathrm{g}$ of misoprostol followed by $400 \mu \mathrm{g}$ every $3 \mathrm{~h}$ up to a maximum of 5 doses or until the abortion occurs, whichever occurs early. In the control group only misoprostol was inserted in the same dose regime. The results were analyzed.

Results The success rate in both regimens was $100 \%$. Mean induction abortion interval from the insertion of the first misoprostol tablet was significantly shorter in the mifepristone pretreated group $6.72 \pm 2.26 \mathrm{~h}$ as compared to $12.93 \pm 3.4 \mathrm{~h}$ in the misoprostol alone group $(P<0.001)$. The mean blood loss was slightly higher in the control group. The mean dose of the misoprostol required was significantly less in the study group $1,186 \pm 291.64 \mu \mathrm{g}$ as against $1,736 \pm 320.20 \mu \mathrm{g}(P<0.001)$. The side effects observed in both the groups were similar mainly nausea vomiting, fever, abdominal cramps.
\end{abstract}

Nagaria T. (凹), Professor - Sirmor N., Ex Senior Resident Dept. of Obstetrics and Gynaecology,

Pt. J.N.M Medical College, 28 MIG, Indrawati Colony, Rajatalab, Raipur C G 492001, India

e-mail: triptinagaria@gmail.com
Conclusion Pretreatment with mifepristone $12 \mathrm{~h}$ before intravaginal misoprostol significantly improves the induction abortion interval.

Keywords Second trimester termination of pregnancy mifepristone $\cdot$ Misoprostol

\section{Introduction}

The second trimester termination of pregnancy is increasing because of increased determination of the sex linked genetic, metabolic disorders. Various surgical and medical methods have been tried for the second trimester MTP with varying success and induction abortion interval. Prostaglandins are associated with not only a high success rate but also with a short induction abortion interval. Misoprostol a newer synthetic prostaglandin E1 has proven its efficacy as an abortifacient for second trimester MTP since 1987. It is superior to all other available prostaglandins as it is stable at room temperature, requires no refrigeration, is cost effective, has fewer side effects, is a potent uterotonic and cervical ripening agent, free from bronchoconstrictive effect. It can be used by both the oral as well as vaginal route and in concurrence with other drugs as well. Mifepristone, (RU 486, a substitute 19- norethisterone derivative) by blocking the progesterone receptors causes estrogen dominance and results in intrauterine fetal death. At the same time it sensitizes the uterus to the activity of the prostaglandin. Thus, a 
combination of the two can significantly improve the efficacy of the misoprostol for the termination of second trimester termination of the pregnancy.

\section{Materials and Methods}

The study was conducted on selected 200 cases came for second trimester termination of pregnancy from January 2003 to October 2004. A detailed history of the case regarding menstrual, obstetric, personal, medical with special reference to cardiovascular, respiratory, GIT, endocrinal disorder and coagulopathy was obtained. General and systemic examination of the cases was done. The patients with undiagnosed adnexal masses, hypertension, diabetes, jaundice, severe anemia, heavy smokers, adrenal insufficiency, coagulopathy, on corticosteroid therapy, porphyria, sickling, hemophilia, ITP were excluded from the study.

Proper counseling a written consent were obtained following which the cases were randomly divided in two groups of 100 each. Study group received $200 \mu \mathrm{g}$ of mifepristone on admission. After $12 \mathrm{~h}$ in these cases $600 \mu \mathrm{g}$ of misoprostol was inserted vaginally and thereafter $300 \mu \mathrm{g}$ every $3 \mathrm{~h}$ until the abortion occured or up to a maximum of 5 doses. Control group: the cases received misoprostol only in the same dose schedule. The cases were closely monitored for side effects if any, the onset of contraction, bleeding cervical dilatation each time before insertion of each misoprostol. Induction abortion interval, since the insertion of the first intravaginal tablet of misoprostol was noted down. The process is considered failed if abortion fails to occur in $15 \mathrm{~h}$ of the insertion of the first tablet of misoprostol, incomplete if part or whole of the placenta is retained. If placenta is retained for more than $2 \mathrm{~h}$ surgical evacuation was done. In case of failure another method medical or surgical was tried. Rh antibody was given to all the $\mathrm{Rh}$ negative cases at the end of the procedure. The data were analyzed.

\section{Observations}

Majority of the cases in both the groups were between 21 and 30 years of age. The mean gravidity of the cases was $3.62 \pm 1.35$ years in the study group and $2.9 \pm 1.50$ in the control group. The mean parity was $2.59 \pm 1.34$ and $1.79 \pm$ 1.50 in the study and the control groups, respectively. The mean gestational age was $16.04 \pm 2.57$ and $19.03 \pm 3.92$ weeks in the study and the control groups respectively (Table 1).

$90 \%$ of the cases aborted within $9 \mathrm{~h}$ in the study group after the insertion of the first misoprostol tablet as against only $13 \%$ in the misoprostol alone group. All the cases in the study group aborted within $15 \mathrm{~h}$ in the study group as against only $79 \%$ in the control group. The mean induction abortion interval was $6.72 \pm 2.26 \mathrm{~h}$ as compared to $12.29 \pm 3.41 \mathrm{~h}$ in the control group. $(P<0.001)$ (Table 2$)$.

Success rate was $100 \%$ in both the groups.

The abortion was complete in $95 \%$ of the study group while $90 \%$ in the control group. Need of other oxytocic for control of bleeding was in $14 \%$ of the control group as compared to $5 \%$ in the study group. $(P<0.001)$ (Table 3$)$.

How was it calculated: Mean blood loss was $61.25 \pm 19.67$ and $67.25 \pm 20.14 \mathrm{ml}$ in the study and the

Table 1 Epidemiological factors

\begin{tabular}{|c|c|c|}
\hline Factors & $\begin{array}{l}\text { Mifepristone }+ \\
\text { misoprostol group }\end{array}$ & $\begin{array}{l}\text { Misoprostol } \\
\text { alone group }\end{array}$ \\
\hline \multicolumn{3}{|l|}{ Age } \\
\hline Mean in years & $28.33 \pm 5.08$ years & $25.02 \pm 5.76$ years \\
\hline Minimum & 15 years & 16 years \\
\hline Maximum & 43 years & 35 years \\
\hline \multicolumn{3}{|l|}{ Gravidity } \\
\hline Mean & $3.62 \pm 1.346$ & $2.9 \pm 1.520$ \\
\hline Minimum & 1 & 1 \\
\hline Maximum & 7 & 10 \\
\hline \multicolumn{3}{|l|}{ Parity } \\
\hline Mean & $2.592 \pm 1.34$ & $1.791 \pm 1.50$ \\
\hline Minimum & 0 & 0 \\
\hline Maximum & 6 & 6 \\
\hline \multicolumn{3}{|l|}{ Gestational age } \\
\hline Mean in weeks & $16.04 \pm 2.57$ & $19.03 \pm 3.92$ \\
\hline Minimum & 12 weeks & 12 weeks \\
\hline Maximum & 24 weeks & 28 weeks \\
\hline
\end{tabular}

Table 2 Distribution of the cases according to the onset of events since the insertion of the first misoprostol tablet

\begin{tabular}{llll}
\hline Duration in hours & $\begin{array}{l}\text { Mifepristone }+ \\
\text { misoprostol group } \\
N=100 \text { no. }\end{array}$ & $\begin{array}{l}\text { Misoprostol } \\
\text { alone group } \\
N=100 \text { no. }\end{array}$ & $P$ value \\
\hline Start of contraction & & & \\
$<2$ & 11 & 1 & $<0.001$ \\
$2-4$ & 45 & 5 & $<0.001$ \\
$4-6$ & 75 & 19 & $<0.001$ \\
$6-12$ & 100 & 92 & - \\
Mean \pm SD & $4.66 \pm 2.03$ & $8.18 \pm 2.68$ & $<0.001$ \\
Start of bleeding & & & $<-0.01$ \\
$<2$ & 4 & 2 & $<0.001$ \\
$2-4$ & 40 & 6 & $<0.001$ \\
$4-6$ & 51 & 9 & $<0.01$ \\
$6-12$ & 100 & 76 & $<0.001$ \\
Mean \pm SD & $5.52 \pm 2.13$ & $9.89 \pm 3.12$ & \\
\hline
\end{tabular}


Table 3 Distribution of the cases according to the induction abortion interval

\begin{tabular}{|c|c|c|c|c|c|c|}
\hline $\begin{array}{l}\text { S. } \\
\text { no. }\end{array}$ & $\begin{array}{l}\text { I.A.I. duration } \\
\text { in hours }\end{array}$ & $\begin{array}{l}\text { Mifepristone }+ \\
\text { misoprostol } \\
\text { group } \\
N=100 \text { no. }\end{array}$ & & $\begin{array}{l}\text { Misoprostol } \\
\text { alone group } \\
N=100 \text { no. }\end{array}$ & & $P$ value \\
\hline 1 & $0-3$ & 03 & 97 & 0 & 50 & - \\
\hline 2 & $3-5$ & 25 & 100 & 02 & 79 & $<0.001$ \\
\hline 3 & $5-7$ & 52 & - & 02 & 100 & $<0.001$ \\
\hline 4 & $7-9$ & 90 & & 13 & & $<0.001$ \\
\hline \multicolumn{2}{|c|}{ Mean \pm SD } & $6.72 \pm 2.26$ & & $12.29 \pm 3.14$ & & $<0.001$ \\
\hline \multicolumn{2}{|c|}{ Minimum } & $2 \mathrm{~h}$ & & $5 \mathrm{~h}$ & & \\
\hline \multicolumn{2}{|c|}{ Maximum } & $13 \mathrm{~h}$ & & $21 \mathrm{~h}$ & & \\
\hline
\end{tabular}

The induction abortion interval is significantly shorter in the combination group

control group, respectively $(P>0.05)$ (Table 3$)$. Majority of the fetus in both the groups were aborted dead, 87 and $90 \%$, in sac in $12 \%$ of the study group and $5 \%$ in the control group, respectively. The mean dose of the misoprostol required was significantly less in the study group $1,186 \pm 291.64 \mu \mathrm{g}$ as compared to $1,736 \pm 320.20 \mu \mathrm{g}$ in the control group, respectively $(P<0.001)$ (Table 3$)$.

The side effects observed were mainly nausea, vomiting 10 and $14 \%$, fever 18 and 23\%, abdominal cramps 10 and $13 \%$, flushing and diarrhea in $2 \%$ each in the study and control group, respectively (Table 4).

\section{Discussion}

Misoprostol has proven its efficacy as an effective abortifacient for the second trimester termination of pregnancy. It is being successfully used through all the routes i.e. sublingual, oral and vaginal and in different regimens with the induction abortion interval varying from $12 \mathrm{~h}$ to as high as $33 \mathrm{~h}$. [1-9].

Combination of mifepristone with misoprostol is now widely used method for first early first trimester pregnancy termination. Priming of the uterus with mifepristone makes it more sensitive to prostaglandins. It binds with the progesterone receptors and antagonizes the actions of progesterone on prostaglandin synthesis and metabolism resulting in increase in production and decreased deactivation of prostaglandins. It also induces cervical softening thus, enhancing the efficacy of the prostaglandins as an abortifacient.

The time interval between the insertion of the first tablet of misoprostol and start of contraction was significantly shorter in the study group $4.66 \pm 2.03$ as against $8.18 \pm 2.68$ in the misoprostol alone group $(P<0.001)$. The time interval
Table 4 Distribution of cases according to the outcome of the methods

\begin{tabular}{llll}
\hline Outcome & $\begin{array}{l}\text { Mifepristone }+ \\
\text { misoprostol } \\
\text { group } \\
N=100 \text { no. }\end{array}$ & $\begin{array}{l}\text { Misoprostol } \\
\text { alone group } \\
N=100 \text { no. }\end{array}$ & $P$ value \\
\hline Success rate & 100 & 100 & - \\
Complete ab. rate & 95 & 90 & $<0.05$ \\
Placenta retained & 05 & 10 & $<0.001$ \\
Pieces & 03 & 8 & $<0.001$ \\
Whole placenta & 02 & 2 & $>0.05$ \\
Need for oxytocic & 05 & 14 & $>0.05$ \\
Blood loss in ml & & & $>0.05$ \\
$\quad<50$ ml & 59 & 48 & $>0.05$ \\
50-100 ml & 41 & 51 & \\
Mean blood loss & $61.25 \pm 19.67$ & $67.25 \pm 20.25$ & \\
Minimum in ml & 25 & 25 & $<0.001$ \\
Maximum in ml & 100 & 125 & $<0.001$ \\
Ensac abortion & 12 & 5 & \\
Dead & 87 & 90 & \\
Mean dose of & $1,186 \pm 291.64$ & $1,736 \pm 320.20$ & \\
misoprostol required & & & \\
\hline
\end{tabular}

between the insertion of the first tablet and the start of the bleeding was also significantly shorter in the study group $5.52 \pm 2.13 \mathrm{~h}$ as compared to $9.98 \pm 3.12 \mathrm{~h}$ in the control group. $(P<0.001)$. The induction abortion interval was significantly shorter $6.72 \pm 2.26 \mathrm{~h}$ in the study group while it was $12.29 \pm 3.41 \mathrm{~h}$ in the misoprostol alone group. $(P<0.001)$.

Rodger et al. [10] in a double blind study using $600 \mathrm{mg}$ mifepristone $36 \mathrm{~h}$ prior to gemeprost found that the IAI was significantly reduced to $6.8 \mathrm{~h}$ as compared to $15.8 \mathrm{~h}$ in the placebo group. Similar results had been observed by other authors as well using mifepristone followed by prostaglandins [11-15] (Table 4).

The success rate was $100 \%$ in the present study. The mean dose of misoprostol required was significantly less when used in combination with mifepristone as is also found in many other studies. The commonly observed side effects were nausea, vomiting, fever, abdominal cramp and diarrhea.

\section{Conclusion}

Second trimester termination of the pregnancy using combination of mifepristone and misoprostol is a safe, non invasive, highly cost effective method with a high success rate a short IAI. Pre-treatment with mifepristone adds to the effectiveness of the misoprostol as an abortifacient. 


\section{References}

1. Wong KS, Ngai CS, Yeo EL, et al. A comparison of two regimen of intravaginal misoprostol for termination of second trimester pregnancy: a randomized trial. Hum Reprod. 2000;15:709-12.

2. Herbutya Y, Chanarchakul B, Punyavachira P. Vaginal misoprostol in the termination of second trimester pregnancy. J Obstet Gynaecol Res. 2000;26:121-5.

3. Pongsatha S, Tongsong T. Second trimester pregnancy termination with $800 \mathrm{mcg}$ vaginal misoprostol. J Med Assoc Thai. 2001;84: 859-63.

4. Herbutya Y, Chanarchakul B, Punyavachira P. Second trimester pregnancy termination: a comparison of 600 and $800 \mu \mathrm{g}$ of intravaginal misoprostol. J Obstet Gynaecol Res. 2001;27:125-8.

5. Gilbert A, Reid R. A randomized trial of oral versus vaginal administration of misoprostol for the purpose of mid trimester termination of pregnancy. Aust N Z J Obstet Gynaecol. 2001; 41:407-10.

6. Ramin KD, Ogburn PL, Danilenko DR, et al. High dose oral misoprostol for mid trimester pregnancy interruption. J Gynecol Obstet Invest. 2002;54:176-9.

7. Dickinson JE, Evans SF. A comparison of oral misoprostol with vaginal misoprostol administration in second-trimester pregnancy termination for fetal abnormality. Obstet Gynecol. 2003;102: 1294-9.

8. Tang OS, Lau WNT, Chan CCW, et al. A prospective randomized comparison of sublingual and vaginal misoprostol in second trimester termination of pregnancy. $\mathrm{Br} \mathrm{J}$ Obstet Gyneacol. 2004;11:1001-5.

9. Pongastha $\mathrm{S}$, Tong song $\mathrm{T}$. Therapeutic termination of second trimester pregnancies with intrauterine fetal death with $400 \mu \mathrm{g}$ of oral misoprostol. J Obstet Gynaecol Res. 2004;30:217-20.

10. Baird DT, Rodger MW. Pretreatment with mifepristone (R U 486) reduces interval between prostaglandin administration and expulsion in second trimester abortion. Br J Obstet Gyneacol. 1990;97:41-5.

11. Hinshaw K, Refaey HE. Mid trimester termination for fetal abnormality: advantages of a new regimen using mifepristone and misoprostol. Br J Obstet Gyneacol. 1995;102:559-60.

12. Refaey HE, Templeton A. Induction of abortion in the second trimester by a combination of misoprostol and mifepristone: a randomized comparison between two misoprostol regimens. Hum Reprod. 1995;10:475-8.

13. HO PC, Tsang SSK, Ma HK. Reducing the induction to abortion interval in termination of second trimester pregnancies: a comparison of mifepristone with laminaria tent. Br J Obstet Gyneacol. 1995;102:648-51.

14. Premila WA, Templeton A. Nonsurgical mid trimester termination of pregnancy; a review of 500 consecutive cases. Br J Obstet Gyneacol. 1999;106:706-10.

15. Ngai SW, Tang OS, Pak Chiung HO. Randomized comparison of vaginal $(200 \mu \mathrm{g}$ every $3 \mathrm{~h})$ and oral $(400 \mu \mathrm{g}$ every $3 \mathrm{~h})$ misoprostol when combined with mifepristone in termination of second trimester pregnancy. Hum Reprod. 2001;15:2205-8. 